九州大学学術情報リポジトリ

Kyushu University Institutional Repository

\title{
A SYNOPSIS OF THE BEE GENUS PALAEORHIZA PERKINS (HYMENOPTERA, COLLETIDAE) OF NEW GUINEA PART I. SUBGENUS PALAEORHIZA S. STR.
}

Hirashima, Yoshihiro

https://doi.org/10.5109/2376

出版情報: ESAKIA. 11，pp.89-119，1978-03-31. Entomological Laboratory，Faculty of Agriculture， Kyushu University

バージョン：

権利関係 : 


\title{
A SYNOPSIS OF THE BEE GENUS PALAEORHIZA PERKINS (HYMENOPTERA, COLLETIDAE) OF NEW GUINEA PART I. SUBGENUS PALAEORHIZA S. STR. ${ }^{1 \text { ) }}$
}

\author{
Y oshihiro Hirashima \\ Entomological Laboratory, Faculty of Agriculture \\ Kyushu University, Fukuoka 812, Japan \\ and \\ Hikosan Biological Laboratory, Faculty of Agriculture \\ Kyushu University, Hikosan, Fukuoka 824-07, Japan
}

\begin{abstract}
A new definition is given to the subgenus Palaeorhiza s. str., which is further divided into six species groups. It occurs in Australia, New Guinea, New Britain, Solomon Islands, Amboina, Kai and Timor, and is composed of 13 species. Five new taxa are Palaeorhiza abdominalis, flavipennis, combinata and purpurea spp. n. from Solomon Islands, and P. montana sp. n. from New Guinea. Lectotype of Prosopisviolacea Friese is designated.
\end{abstract}

Undoubtedly the genus Palaeorhiza Perkins is one of the most interesting genera of bees in the' world. As is remarked by Michener (1965), it is indeed the only genus of bees that is centered in New Guinea. Michener (1965) enumerated about sixty species, which he divided into four subgenera. In 1975 I described seven more species of Palaeorhiza from New Guinea. I have still very many unnamed species in our collection. I do not really know the extent of the genus but I suppose it is composed of a few hundred species.

Species of Palaeorhiza are exceedingly variable in the external structures. Therefore, they may be divided into many subgenera. The aspect of the structural variations will be disclosed and discussed in the series of this paper. In regard to the coloration, the species of Palaeorhiza are also very variable. They are usually beautiful metallic, with or without yellow markings, but sometimes they are fulvous or yellowish, or partly reddened, or black and red, or rarely nearly all black. The coloration is variable even in one subgenus such as Palaeorhiza s.str. as shown in this paper. They are also variable in size, small to large, but the largest one, so far as I know, does not exceed the honey bee, although they are much less

1) Contribution from the Entomological Laboratory, Faculty of Agriculture, Kyushu University, Fukuoka (Ser. 3, No. 47) and that from the Hikosan Biological Laboratory, Faculty of Agriculture, Kyushu University, Hikosan (Ser. 2, No. 37). 
robust than the latter.

Interestingly, Palaeorhiza has a distribution similar to that of the birds of paradise. The type species of the genus is known from Australia, although it is not a dominant group of bees in that continent.

In this paper the subgenus Palaeorhiza s. str. alone is discussed, to which thirteen species are included.

\section{Subgenus Palaeorhiza Perkins}

Palaeorhiza Perkins, 1908, Proc. Hawaiian Ent. Soc., 2: 29; Michener, 1965, Bull. Amer. Mus. Nat. Hist., 130: 145.

Type-species : Prosopis perviridis Cockerell, 1905. (Monobasic and original designation)

The subgenus is here used in a different sense from that of Michener (1965). I include, in this subgenus, only six out of thirty-seven names of his group " a" of Palaeorhiza s. str. They are perviridis, cassiaefloris, caerulescens, reginarum, malachisis and violacella. In addition, five new species are described and three more species are also treated in this paper. Thus, this subgenus is neither a very small group nor a very large one, but is recognizable as a distinct natural group, although the coloration of the integument and wings is highly variable.

The subgenus is most distinctive in that the propodeum is provided with a pair of small prominences at each apex of the dorsolateral faces close to the enclosure, and the latter is longitudinally concaved on the apical portion between the prominences. In the females of perviridis, caerulescens, reginarum and malachisis, the prominences are small and widely separated from each other, and the depression of the apical portion of the enclosure is not deep, although it is well indicated. In the female of an unnamed species from New Britain the prominences are very distinctive, and the apical depression of the enclosure between them is also deep. In the females of abdominalis, purpurea, combinata, flavipennis and montana, the prominences are not very distinctive as in the New Britain species but well indicated, and the apical depression of the enclosure is also distinctive. These structures are also distinctive in the males, although they are known only in perviridis, reginarum, malachisis, violacella, montana and purpureoventris at present.

The inner hind tibial spur of the female is coarsely pectinate. This is also one of the most distinctive characters of this subgenus.

Basitibial area of the female hind legs is well indicated by a slender, slightly elevated, smooth and shining space, but it is not keeled or edged laterally. It is obscure in montana only, in which the basal portions of the hind tibiae are unusually slender.

At the apex of the last exposed tergum of the female, there is a small elongate area which is smoother and shinier than the rest of the tergum. It is named here as an incomplete pygidial plate. It is usually rather difficult to observe because of its small size and the presence of hairs on the tergum. In montana only it is obscure, but the apex of the last exposed tergum is narrowly and triangularly distinctly produced apically than in other species.

The supraclypeal area is large, long, and the upper limit is obscure. The upper portion of the supraclypeal area is still convex longitudinally, not sharply 
separated or defined from the frons. The latter is also convex in the middle. These structures are more pronounced in the female than in the male.

In the male, the underside of the thorax is broadly and often deeply concaved, and this portion is covered with sparse to very dense hairs. The covering hairs are very dense and conspicuous (snow white) in reginarum, dense in malachisis, rather sparse in montana and sparse in perviridis, violacella and purpureoventris (the males of other species are unknown).

The male sterna are also characteristic as described below.

The species of this subgenus are variable in the coloration of the integument and wings. The integument is strongly metallic (green, blue green or purple) except for abdominalis which is primarily black and red. The yellow markings, sometimes orange, pale, or pale with blue tint, are usually present, although not extensively, on the head, thorax and legs, or at least on the head and fore legs, but the females of malachisis and flavipennis are not decorated with such a pale marking. On the contrally, in the females of two unnamed species (one from New Guinea and another from New Britain) the head and thorax are richly decorated with the yellow makings. Interestingly, three basal terga of them are provided with dense white apical hair bands, although they are broadly interrupted, Wings are hyaline in perviridis, cassiaefloris and violacella, smoky or slightly darkened in most species, yellowish in abdominalis and distinctly yellowish in flavipennis.

\section{Description of the subgenus}

Rather large to large species, usually robust except for female montana which is more or less slender.

Strongly metallic, green, blue or purple, or in combination; in abdominalis only head and thorax black and metasoma red basally; yellow or pale markings, usually not extensive except for two unnamed species, on anterior part of body, rarely absent. Wing coloration variable, hyaline to dark or yellowish.

Mandibles bidentate or tridentate in female, bidentate in male; malar space usually short, less than basal width of mandibles; supraclypeal area large, long, well convex, upper limit obscure and almost extending to mid ocellus; median sulcus of supraclypeal area distinct, long; frontal line, which is a continuation of the latter, weak, not longer than the latter; space between ocelli and preoccipital carina fairly broad and usually slanting toward the carina.

Collar of pronotum rather low (perviridis) to distinctly elevated (flavipennis) ; mesoscutum with or without a pair of longitudinal ridges between median and parapsidal lines; propodeum with a pair of small to large prominences on apical portion close to enclosure; propodeal enclosure usually large, smooth and shining in the Australian species, apical portion slightly to distinctly longitudinally concaved, lateral margin indicated by either distinct sulcus (sometimes weaker) or absence of punctures ; episternal scrobe usually distinct; carinae in front of mid coxae weak to strong; underside of male thorax largely and deeply concaved, clothed with sparse to very dense hairs.

Stigma slender to slightly widened ; second submarginal cell about or less than three-fourths as long as first. 
Inner hind tibial spur of female coarsely pectinate; basitibial area of female, which is absent in montana only, is indicated by a slender, slightly elevated, smooth and shining space at each base of hind tibiae ; claws moderate in female, rather strong in male.

Second tergum often convex in middle; interrupted bands of dense white hairs present on three basal terga in females of two unnamed species; incomplete pyg $i$ dial plate present in female except montana only, in which apical portion of sixth tergum distinctly produced apically ; basal portion of female third sternum sometimes concaved transversely; apical margin of male second sternum triangularly produced apically in middle; male third sternum with a pair of distinct longitudinal ridges, absent in violacella only; male fourth sternum with a pair of similar ridges or low prominences basally, absent in violacella only; basal halves or more of lateral portions of male third and fourth sterna closely punctate or punctate-striate except for violacella only; male fourth and fifth sterna either with a row of fringe of hairs on apical margin or with a tuft of hairs on apical portion (hairs on apical portion obscure in violacella and absent in malachisis only).

Seventh tergum of male narrowed apically, apical margin usually slightly emarginate in middle, with tuft of long black hairs on lateral portions; male genitalia rather small, simple; penis valve distinctly exceeding tip of gonostylus, without dorsolateral wing.

Distribution: Australia, New Guinea, New Britain, Solomon Islands, Kai, Amboina and Timor. The type species is known from Australia.

The subgenus may be divided into six species groups, as follows:

1). Species group of abdominalis. Four species: abdominalis, combinata, pur purea and flavipennis. All are knwon from Solomon Islands. Mandibles of female tridentate, broad at apices; malar space distinctly narrowed anteriorly ; clypeoocular distance short; collar of pronotum elevating dorsally, arcuate as seen in front; mesoscutum with a pair of longitudinal ridges, strong in abdominalis, weak in other species; enclosure of propodum more or less small, almost all dorsal, deeply longitudinally concaved on apical portion ; ventral portions of first tergum punctate for full space ; punctures on pre- and mesepisternum dense (irregular in size, not strong) ; punctures on metepisternum very weak or almost absent; coloration of integument and wings very variable ; wings with very dense, short hairs; in purpurea and combinata, propodeal enclosure yellow. No male is known.

This is further divided into three subgroups according to their coloration, as follows :

a). Subgroup of abdominalis. One species; head and thorax black, legs red, and metasoma red basally and metallic blue-black apically'; yellow markings restricted to lateral portions of face only; wings yellowith.

b). Subgroup of flavipennis. One species; dark blue-green with purple tint, without yellow marking; legs blackish ; wings distinctly yellowish including veins and stigma.

c). Subgroup of purpurea. Two species, purpurea and combinata; yellow markings on head and thorax; propodeal enclosure entirely yellow. 
2). Species group of montana. One species, but probably purpureoventris (the female is unknown) is included in this species group. Known from W. New Guinea. Similar to the abdominalis group in having the tridentate female mandibles, longitudinal ridges on mesoscutum and very finely punctate metepisternum, but differs in having the following features : female malar space broad and only slightly norrowed anteriorly ; clypeo-ocular distance broader ; female second tergum highly convex in middle; mesepisternum sparsely punctate, punctures strong; and head with three yellow stripes in front and two behind. Male fourth and fifth sterna each with a row of fringe of hairs on apical margins. Female montana is distinctive in that the fore tarsi are slim with poor polliniferous hairs, the last exposed tergum distinctly produced apically with a strong sting and the basitibial area absent. These features might suggest that montana may be parasitic.

3). Species group of peruiridis. Three species, perviridis, reginarum and caerulescens. All are known from Australia. Mandibles of female bidentate ; malar space rather narrow, only slightly narrowed anteriorly ; clypeo-ocular distance rather wide ; collar of pronotum rather low; enclosure of propodeum large, smooth and shining, only slightly concaved apically, laterally defined by strong, often punctate sulcus, apical one-third or more of enclosure on vertical face; apical prominences of propodeum widely separated ; second tergum distinctly convex in middle; face with three yellow stripes, the median one interrupted at summit of clypeus and about middle of supraclypeal area; upper mark on supraclypeal area spear head-like ; ventral portions of first tergum broadly impunctate on basal' portions; male fourth and fifth sterna each with a tuft of hairs on apical portion (hairs not arranged in a fine row) ; male third and fourth sterna with laterobasal portions punctate-striate; punctures on pre- and mesepisternum rather strong to strong, not dense ; metepisternum distinctly punctate.

4). Species group of malachisis. One species known from Kai and Amboina. Somewhat intermediate between the abdominalis and perviridis groups. Mandibles of female weakly tridentate with broad apex similar to the abdominalis group; malar space more or less distinctly narrowed anteriorly; clypeo-ocular distance short ; propodeum similar to the perviridis group but enclosure less shining; preand mesepisternum densely and strongly punctate (punctures denser than in the perviridis group and stronger than in the abdominalis group); punctures on metepisternum distinct as in the perviridis group; entirely without yellow marking except for face of male; male fourth sternum without fringe of hairs.

5). Species group of violacella. This is known by the male of a single species from Timor. Distinctive in having the second submarginal cell not receiving first recurrent vein, vein $r$ subequal to upper margin (Rs) of second submarginal cell in length, and third and fourth sterna normal. Ivory white markings limited to face only; clypeo-ocular distance short ; propodeal enclosure more or less similar to the perviridis group but distance between prominences on the apical portion of propodeum shorter and lateral margin of enclosure indicated by weak line; second tergum convex ; mesepisternum densely punctate ; metepisternum distinctly punctate.

6). Group of two unnamed species, one from New Guinea and another from New Britain. Head, thorax and legs richly decorated with yellow markings; three 
basal terga with interrupted bands of dense white hairs on apical margins. Males are unknown.

Key to the groups and SPECIES OF Palaeorhiza s. str.

\section{Females}

1. Three basal terga with interrupted bands of dense white hairs on apical margins ; head, thorax and legs with rich yellow markings (mesoscutum also with yellow markings) .......... Two unnamed species from New Guinea and New Britain

- Metasoma without hair bands; head and thorax with or without yellow markings (mesoscutum always without yellow marking)

2. Mesoscutum with a pair of longitudinal ridges between median and parapsidal lines, although sometimes weak or obscure in the species from Solomon Islands; apical prominences of propodeum rather close to each other (more or less widely separated in montana only); propodeal enclosure long, rather narrowed apically, all or almost all dorsal, apical portion distinctly longitudinally concaved ; lateral margin of propodeal enclosure indicated by absence of punctures; metepisternum almost impunctate or only with very weak punctures; color variable

(Groups of montana and abdominalis).....3

- Mesoscutum without longitudinal ridges ; apical prominences of propodeum widely separated (because apical portion of propodeal enclosure broad); propodeal enclosure large, much broader than long when seen from above, usually smooth and distinctly shining, apical portion between propodeal prominences slightly concaved, one-third or more of apical portion on vertical face; lateral margin of enclosure defined by strong punctate sulcus except for malachisis in which it is defined by weaker line; metepisternum distinctly punctate, although punctures small .........................(Groups of malachisis and perviridis)......7

3. Head with five yellow stripes, three in front and two behind; thorax and metasoma without pale marking; head and thorax steel blue with distinct purple tint; metasoma strongly purple, with slight green tint in some light; legs piceous; second tergum strongly convex in middle ; pre- and mesepisternum sparsely and strongly punctate; malar space more or less broad, slightly narrowed anteriorly ; hind tibiae very slender basally, basitibial area not well indicated; the last exposed tergum distinctly produced apically with strong sting ................................................................

- Face without median yellow stripe ; malar space distinctly narrowed anteriorly ; pre- and mesepisternum distinctly and densely punctate; ventral portions of first tergum punctate all over ; wings with unusually dense, short hairs... . . . . . . .

(Group of abdominalis).....4

4. Head and thorax black; metasoma red basally, blackish blue apically; face with narrow stripes of yellow at sides; clypeus with an evanescent pale marking on apical portion ; mesoscutum densely and strongly rugoso-punctate, dull, with longitudinal ridges conspicuous ..........................abdominalis sp. n. Solomon Islands

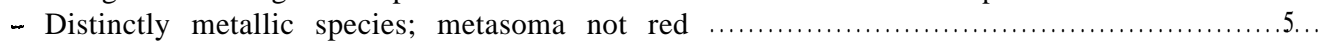

5. Head, thorax and metasoma dark blue-green, with purple tint, entirely without pale marking; wings strongly yellowish, veins and stigma also yellow; legs nearly black flavipennis sp. n. Solomon Islands

- Head and thorax with yellow markings; propodeal enclosure yellow; wings not distinctly yellowish 
6. Green species; legs red ; head and thorax with yellow markings as follows: basal spots on mandibles, apical small spot on clypeus, spear head-like mark on upper portion of supraclypeal area, lines along inner margins of eyes, evanescent spots or lines on genal areas along eye margins, interrupted band on collar of pronotum, round spots on tubercles, round spot on prepisternum above, similar spot on metepisternum above, triangular marks on axillae, lateral stripes on scutellum and full space of propodeal enclosure; mesoscutum strongly and densely rugoso-punctate ................................... combinata sp. n. Solomon Islands

- Purple species ; legs also purple with yellow markings; yellow makings on head and thorax similar to preceding species except for collar of pronotum entirely

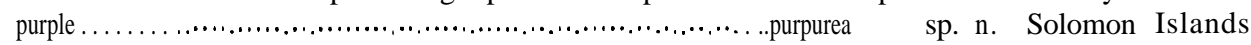

7. Dark blue-green species with purple tint, entirely without yellow marking; malar space not broad, narrowed anteriorly; clypeo-ocular distance narrow ; pre- and mesepisternum densely nearly regoso-punctate; hairs on metasoma blackish ................................................ malachisis (Smith). Kai and Amboina Head and thorax with yellow markings but those on the latter scarce ; propodeal enclosure large, usually distinctly shining, defined by punctate sulcus laterally; apical depression of propodeal enclosure weak; pre- and mesepisternum sparsely punctate .............................................................(Group of perviridis $\ldots \ldots . .8$

8. Blue, large species; wings darkened, with dense hairs as usual ; cell first $\mathrm{Cu}$ of fore wing with hairs; mesoscutum with punctures often dense and strong; third tergum with hairs black, whitish only at sides; fourth and following segments with hairs black; upper mark on supraclypeal area separated by median sulcus ..................................................... reginarum (Cockerell). Australia

- Green or blue-green species; wings hyaline, with hairs very sparse; cell first $\mathrm{Cu}$ of fore wing free of hairs; four basal terga with hairs white; upper mark on supraclypeal area not separated by median sulcus; punctures on mesoscutum

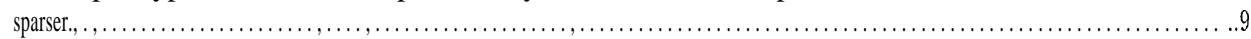

9. Green species, rarely bluish, but at least third and following terga green; apical segments of metasoma often retractile; third tergum with minute punctures along lateral margins, which are considerably weaker than coarse punctures on lateral portions of the same tergum ............................perviridis (Cockerell). Australia

- Blue-green species with purple tint, which is strong on metasoma; apical segments of metasoma not retractile; third tergum without fine punctures along lateral margins caerulescens (Friese).

Australia

\section{MALES}

1. Third and fourth sterna unmodified; wings with vein $r$ subequal to upper margin (Rs) of second submarginal cell; first recurrent vein ending outside second submarginal cell (basal to first transverse cubital); inner eye margins strongly converging below; head and thorax purple with slight green tint except for propodeum more greenish and enclosure blue-green when seen from certain angles; face with ivory white markings as follows: rather large apical mark of clypeus and lateral face marks not beyond level of antennal sockets; metasoma shining purple with very slight blue-green tint as seen in certain angles; legs purple with slight blue-green tint; anterior face of tibiae and distitarsi of fore legs yellowish ............................................................ violacella (Michener). Third sternum with a pair of longitudinal ridges; fourth sternum with a pair of low prominences or longitudinal ridges; third and fourth sterna with laterobasal portions densely punctate-striate

Timor 
2. Fourth sternum with a row of fringe of dense, rather long hairs on apical margin ; similar hair fringe on apical margin of fifth sternum . . (Group of montana).....3

- Fourth and fifth sterna without a row of fringe of hairs on their apical margins, but with or without tuft of rather dense hairs on apical portions . . . . . . . . . . . . (Groups of malachisis and perviridis) ......4

3. Head and thorax blue, shining; markings on head, thorax and legs rather rich, pale yellow, partly bluish; markings on thorax as follows: band on collar of pronotum broadly interrupted in middle, a pair of long, slender stripes (yellowish blue) on mesoscutum slightly elevated, small evanescent marks at sides of mesoscutum, transverse marks on axillae, rather large mark on prepisternum below tegula, similar mark on suprascrobal area, and similar mark on upper portion of metepisternum ; metasoma purple ; very large species....

.purpureoventris Hirashima. W. New Guinea

- Head and thorax not strongly shining metallic, dark blue, variegated with purple and brassy; pale markings limited to head and fore legs only; head with five orange stripes, three in front and two (narrow and short) behind; mesoscutum with a pair of long, weakly elevated, longitudinal ridges between median and parapsidal lines .....................................montana sp. n. W. New Guinea

4. Thorax without yellow marking; pale yellow markings on head and legs as follows: triangular mark on apical part of clypeus, stripes along inner eye margins only slightly exceeding upper tangent of antennal sockets, spots on apices of fore femora, anterior faces of fore tibiae, and spots on bases of mid tibiae ; fourth sternum without fringe of hairs ; concavity on underside of thorax covered with dense hairs ................................ malachisis (Smith). Kai and Amboina

- Thorax with yellow markings at least on pronotum and upper portion of prepisternum . .5

5. Concavity on underside of thorax not sharply defined, with sparse white hairs; head and thorax primarily green; transscutal suture of mesoscutum yellow ; wings hyaline ; cell first $\mathrm{Cu}$ of fore wing almost free of hairs; four basal terga with hairs white ..............................................perviridis (Cockerell). Australia

- Concavity on underside of thorax sharply defined, covered with very dense, densely branched, white hairs ; head and thorax primarily blue; transscutal suture of mesoscutum without yellow marking; wings darkened; cell first $\mathrm{Cu}$ of fore wing hairy; two basal terga only with hairs white (some brown hairs present on second tergum apically) reginarum (Cockerell). Australia

\section{Species group of abdominalis}

\section{(1) Palaeorhiza (Palaeorhiza) abdominalis sp. $\mathbf{n}$.}

This species is unique in having the head and thorax black and the metasoma red basally. This is also very distinctive in having a pair of strong longitudinal ridges on the mesoscutum. The wings are yellowish and the legs with tibiae and tarsi are red. Thus, the recognition of this species is rather easy.

Female : Length about $9.5 \mathrm{~mm}$; wing length $8 \mathrm{~mm}$.

Relative head measurements ; width, 7.7; length, 7.2 ; eye length, 6.0; upper interocular distance, 4.0; width of face, 5.0; lower interocular distance, 3.6 ; clypeal length, $2.3: 0.8$ (the length from the upper margin of clypeus to the tangent running the apices of eyes : the length from the latter to the apex of clypeus). Inner eye margins moderately converging below except for upper portions which 
rather strongly converges toward ocelli; mandibles weakly tridentate ; malar area not broad, distinctly narrowed anteriorly ; labrum with a median process deeply excavated in middle ; face distinctly convex, arched as seen in profile; clypeus with three longitudinally raised areas rather broad but not distinct; supraclypeal area broad and well convex between antennal sockets; frontal line indicated by a flat, more or less broad line ; postocellar distance less than one and one-half times as long as long axis of lateral ocellus, about or a little longer than two-thirds of ocellocular distance ; genal area receding below, space along orbit longitudinally elevated. First segment of flagellum about as long as broad; second shorter than first; third about as long as broad, longer than first. Collar of pronoturn thick, distinctly convex dorsally, median portion narrowed, notched in middle ; a pair of longitudinal ridges on mesoscutum between median and parapsidal lines strongly elevated, smooth, only obscured at marginal areas; propodeal enclosure slightly shorter than scutellum when seen from above, almost all dorsal except for apex only on vertical face of propodeum, deeply concaved longitudinally, especially on apical portion; apical prominences of propodeum lateral to the enclosure not very distinct but the corresponding portions distinctly elevated because the enclosure being distinctly concaved ; ridges in front of mid coxae rather weak. Stigma rather narrow ; second submarginal cell about three-fourths as long as first ; first abscissa of second submarginal cell one-half as long as first transverse cubital, slightly longer than third abscissa. Basitibial area well indicated, smooth, shining and free of hairs ; inner hind tibial spurs very strongly pectinate (considerably more strongly so than in perviridis and reginarum). First tergum more or less short, well convex at basal angle; second tergum slightly constricted at base, weakly convex medially as seen in profile; apical margin of second tergum slightly produced apically in middle when seen from above.

Clypeus longitudinally (but more or less irregularly) rugulose, almost impunctate except at sides ; supraclypeal area longitudinally striate-punctate ; frons and upper paraocular areas densely, rather coarsely punctate; lower paraocular areas longitudinally weakly lineolate with much weaker punctures; genal area weakly lineolate and somewhat coarsely punctate except for narrow space along orbit where nearly smooth, and finely and sparsely punctate. Mesoscutum densely nearly ruguso-punctate, punctures not specially strong ; scutellum with punctures sparser than in mesoscutum; metanotum weakly and sparsely punctate ; propodeum, except for impunctate enclosure which is only feebly shining, closely punctate, punctures much weaker than those on mesoscutum; lateral face of propodeum, which is covered with dense short hairs, with punctures obsolescent except for dorsal margins ; pre- and mesepisternum closely and distinctly punctate, punctures weaker than those on mesoscutum, slightly stronger than those on propodeum, irregular in size; metepisternum, which is covered with not specially dense hairs, almost impunctate or with indication of microscopical punctures. Head and thorax rather dull. Metasoma more or less shining; terga weakly punctate on microscopically tessellate ground ; ventral portions of first tergum finely punctate for full space; punctures on second tergum slightly irregular in size and distribution, rather sparse medially; impunctate apical margin of first tergum narrow, not distinctly indicated, that of second also narrow, more distinct than in first, that of third 
slightly broader than in second; sterna strongly punctate.

Color: Head black except as follows : narrow stripes along inner eye margins pale yellow, suffused with pale brown above ; apical small mark on clypeus and short subbasal lines on mandibles reddish brown or nearly so, not sharply marked. Flagellum reddish brown beneath, darker above. Thorax black with obscure steel blue and brassy tints, without yellow marking. Wings, including veins and stigma, pale yellowish, distal margins slightly darkened ; tegulae pale yellow. Legs with coxae, trochanters and femora piceous to reddish brown, tibiae and tarsi red; basal spots on fore and mid tibiae yellow. Metasoma red except as follows: about apical half of third tergum except for lateral portions and following terga blackish with steel blue tint; coloration of sterna similar to corresponding terga except for third which is red except for latero-apical portions steel blue.

Pubescence : Haris on head and thorax pale yellowish brown except for covering of dense short hairs on lateral faces of propodeum brownish grey; hairs on darker parts of legs pale yellowish brown, those on red parts ferruginous; hairs on red portions of metasoma whitish to red, those on the rest fuscous to nearly black.

Type material : Holotype female (B1SHOP 11276), Guadalcanal, Suta, 500-1200 m, Solomon Is., 27. vi. 1956 (J. L. Gressitt).

Type depository: B. P. Bishop Museum, Honolulu.

Distribution : Solomon Is.

\section{(2) Palaeorhiza (Palaeorhiza) flavipennis sp. $\mathbf{n}$.}

This is a dark blue-green species which has an enamel-like shade on the head and thorax. No pale marking is present on any part of the body except for a few evanescent markings on the face and tibiae. The wings are strongly yellowish, from which the specific name has been derived, including the veins, stigmae and hairs.

Female : Length slightly less than $10 \mathrm{~mm}$; wing length about $8 \mathrm{~mm}$.

Relative head measurements: width, 8.4; length, 7.3; eye length, 6.3; upper interocular distance, 4.2 ; width of face, 5.3 ; lower interocular distance, 3.7; clypeal length, $2.7: 0.6$. Inner eye margins rather strongly converging below except for upper one-fourth which distinctly converges toward ocelli ; mandibles tridentate ; median process of labrum deeply excavated in middle; malar space narrow anteriorly, broadened posteriorly; face well convex and arched as seen in profile ; clypeus with three longitudinally raised areas, the median one broad; frontal line very weak; interocellar distance slightly longer than diameter of lateral ocellus, approximately two-thirds as long as ocellocular distance, a little more than one-half of ocelloccipital distance; genal area narrower than eye when seen from side, longitudinally slightly elevated along eye margins. Collar of pronotum strongly convex dorsally, distinctly arched in front view, slightly emarginate in middle, where narrowed but not carinate, anterior face flat and steep; mesoscutum with a pair of longitudinal raised ridges weak but noticeable; propodeal enclosure subhorizontal but all dorsal, slightly shorter than scutellum wben seen from above, longitudinally broadly and distinctly concaved apically, the depression almost extending to the 
base of enclosure ; apical prominences of propodeum well indicated (although not conspicuous); carinae in front of mid coxae rather strong. Stigma rather slender, slightly widened toward vein $r$; second submarginal cell slightly shorter than fivesixths of first ; first abscissa of second submarginal cell as long as third. Legs rather slender; basitibial area well indicated by elongate, elevated, smooth space; inner hind tibial spur strongly pectinate. Metasoma well convex; first tergum more or less long, distinctly lower than second tergum, roundly converging basally when seen from above; second tergum distinctly convex dorsally as seen in profile, slanting toward constricted base; third tergum largely exposed ; basal portion of third sternum transversely slightly concaved.

Clypeus with punctures not distinct; upper portion of clypeus longitudinally densely rugulose or weakly striate ; supraclypeal area well convex, longitudinally weakly striate-punctate, punctures on median portion stronger than those on clypeus; frons rather densely punctate on smooth and shining ground above, punctures irregular in size, sparse and weak below; lower paraocular area very finely lineolate, weakly punctate; genal area as described for abdominalis, but more shining. Mesoscutum densely punctate on smooth ground, punctures contiguous to one puncture width apart, slightly irregular in size, distinctly weaker than in other species of the same species-subgroup; scutellum slightly more sparsely punctate than in mesoscutum, punctures as strong as or slightly coarser than those on the latter; metanotum weakly punctate on minutely roughened ground ; propodeal enclosure densely microscopically lineolate, not distinctly shining, impunctate ; dorsolateral face of propodeum with punctures weak; lateral face of propodeum nearly dull, very weakly and densely punctate except for dorsal margin where punctate like lateral portion of dorsolateral face; pre- and mesepisternum densely punctate on nearly smooth (microscopically lineolate as seen in certain angles) and shining ground, punctures irregular in size, weak to rather strong.

Metasoma moderately punctate on minutely lineolate and shining ground ; in the holotype, lineolation very weak, and third tergum largely nearly smooth; impunctate apical margins of three basal terga, although not sharply defined, slightly broader than in abdominalis, more distinct than in combinata and purpurea; unlike the latter, lateral portion of apical margin of third tergum impunctate (except for few microscopical punctures), smooth and shining, and this portion as broad as that of perviridis; sterna strongly punctate.

Color: Head and thorax dark blue-green with purple tint, shining with enamellike shade; lateral portion of pronotum, metepisternum and lateral face of propodeum black or nearly so; mandibles shining black; face with following marks obscure reddish brown when seen in certain angles: evanescent short line on apex of clypeus and evanescent lines on sides of face; median portion of clypeus longitudinally purple. Wings strongly yellowish including veins, stigma and hairs which are very short and dense ; distal margins of wings slightly darkened ; tegulae brown or dark reddish brown. Legs piceous with slight purple tint; more than basal halves of fore tibiae yellowish brown anteriorly. Metasoma dark blue-greenish in the holotype, with slight purple tint as seen in certain angles; fourth and fifth terga darker with more purple tint.

Pubescence : Hairs brownish to black except as follows: hairs on metanotum 
and posterior face of propodeum paler, somewhat ochreous; covering of short hairs, which are not specially dense, on lateral face of propodeum greyish brown.

Type material : Holotype female (BISHOP 11277), San Cristoval, Wugiroga, Solomon Is., 8. viii. 1960 (C. W. O'Brien); paratopotype female, same data as the holotype.

Type depository : B. P. Bishop Museum, Honolulu.

Distribution : Solomon Is.

\section{(3) Palaeorhiza (Palaeorhiza) combinata sp. $\mathrm{n}$.}

This is a beautiful green species (slightly darker than in perviridis) having a rather rich decoration of yellow on the head and thorax. This is distinctive in having the propodeal enclosure tinged with yellow. The legs are red except for the basal segments. Thus, this species is easily known by its unique coloration.

Female: Length about $9.5 \mathrm{~mm}$; wing length $8 \mathrm{~mm}$.

Relative head measurements : width, 8.6 ; length, 7.8; eye length, 6.5 ; upper interocular distance, 4.6 ; width of face, 5.6 ; lower interocular distance, 4.0; clypeal length, $2.8: 0.8$. Inner eye margins moderately converging below except for upper one-fourth which rather strongly converges toward ocelli ; mandibles tridentate ; malar space slightly narrower than in abdominalis, distinctly narrowed anteriorly; process of labrum deeply excavated in middle as in abdominalis ; face less convex than in abdominalis, although it is arched as seen in profile; clypeus with three longitudinally raised areas similar to abdominalis except for the median one which is almost carinate on upper portion; supraclypeal area well marked, less convex than in abdominalis ; frons well convex ; postocellar distance about one and one-half times as long as diameter of lateral ocellus, slightly shorter than ocellocular distance, about two-thirds as long as ocelloccipital distance; genal areas narrower than eyes, well convex on upper portions near eyes. Antennae similar to abdominalis, but seven flagellar segments of the left antenna and nine of them of the right one are missing in the holotype. Collar of pronotum distinctly convex dorsally, arched as seen in front, lateral portions with dorsal faces broad and almost flat, median portion distinctly narrowed and notched in middle; mesoscutum well convex, with a pair of longitudinal ridges, which are very strong in abdominalis, obscure but traceable; propodeal enclosure all dorsal, apical portion distinctly concaved, with a median line reaching the base of enclosure ; apical prominences of propodeum well marked; vertical posterior face of propodeum well defined by the prominences on upper portion ; carinae in front of mid coxae weak. Stigma and wing venation similar to abdominalis. Basitibial areas of hind legs well indicated as in abdominalis. Metasoma broad and well convex.

Clypeus distinctly rugose and impunctate in middle; supraclypeal area longitudinally striate with very weak, longitudinal punctures (punctures much weaker than in abdominalis) ; frons strongly, nearly rugoso-punctate ; paraocular areas lateral to antennal sockets finely lineolate, broadly impunctate or punctures sparse and weak near eye margins; genal areas distinctly and rather densely punctate on upper portions (punctures on this portions closer than in perviridis, slightly more distinct than in abdominalis). Mesoscutum strongly, densely and rugosely punctate. 
punctures irregular in size, especially small on anterior margin, punctures on median portion much coarser than in abdominalis; scutellum with punctures sparser than in mesoscutum; metanotum with small punctures ; propodeal enclosure well marked by absence of punctures and by coloration; dorso-lateral face of propodeum more or less coarsely sculptured with small and close punctures; pre- and mesepisternum densely punctate, punctures irregular in size ; metepisternum with indication of dense and microscopical punctures. Metasoma moderately densely punctate on minutely roughened, rather shining ground; punctures on first tergum about as strong as those on metanotum, more or less sparse; punctures on second slightly coarser than those on first; lateral portions of apical margins of three basal terga very finely and densely punctured (the corresponding portions of second and third terga in perviridis impunctate, smooth and shining, especially broadly so on third tergum).

Color: Head, thorax and metasoma green (partly dark green) with slight purple tint; lateral portion of pronotum, metepisternum and lateral face of propodeum blackish; genal area primarily purple with enamel-like shade; mandibles piceous, reddened apically; legs red with coxae and trochanters piceous to reddish brown; yellow markings on head, thorax and legs as follows: small basal marks on mandibles, small spot on apical portion of clypeus, spear head-like mark on upper portion of supraclypeal area (lower half of which is separated by a black median sulcus), long stripes on sides of face extending from anterior basal articulations of mandibles to level of frontal line, evanescent short lines on genal areas along eye margins, band on collar of pronotum narrowed and narrowly interrupted in middle, large triangular marks on axillae, broad longitudinal stripes on lateral portions of scutellum, enclosure of propodeum, large mark on tubercle, round mark on prepisternum and basal marks on tibiae. Wings pale yellowish brown including veins, stigma and tegulae, distal margins slightly darkened ; hairs on wings very short and dense, brownish.

Pubescence: Hairs not conspicuous, ochreous except as follows : dense covering of short hairs on lateral faces of propodeum grey-brown, hairs on apical three terga and sterna black, and those on legs pale ferruginous.

Type material : Holotype female (BISHOP 11278), San Cristoval, Wugiroga, Solomon Is., 8. viii. 1960 (C. W. O'Brien).

Type depository : B. P. Bishop Museum, Honolulu.

Distribution : Solomon Is.

\section{(4) Palaeorhiza (Palaeorhiza) purpurea sp. $\mathbf{n}$.}

This is a beautiful purple species, and is very close to combinata structurally. The mode of yellow maculation is also similar to combinata, but the markings on the thorax, except the propodeal enclosure, which is entirely yellow like combinata, are smaller than the latter.

Female: Length slightly less than $10 \mathrm{~mm}$; wing length a little over $8 \mathrm{~mm}$.

Relative head measurements: width, 8.6 ; length, 7.8 ; eye length 6.5 ; upper interocular distance, 4.5 ; width of face, 5.5; lower interocular distance, 4.0; clypeal length, $2.6: 0.8$. Differs from combinata as follows: Clypeus a little shorter: 
median ridge of clypeus slightly more convex and slightly more distinctly striate longitudinally; interocellar distance a little shorter, about or a little more than twothirds as long as ocellocular distance ; genal area a little less convex on upper portion; head more shining, especially so on frons and vertex; collar of pronotum more narrowed and almost carinate dorsally in middle ; punctures on mesoscutum slightly weaker (although very distinct) and more uniform in size than in combinata; scutellum slightly more densely punctate.

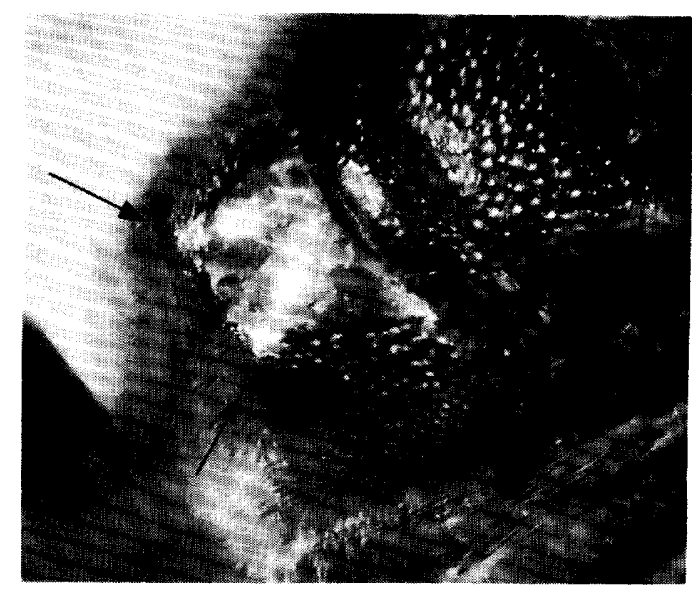

Fig. 1. Palaeorhiza purpurea sp. n., female. Dorsal (slightly oblique) view of the posterior part of the thorax, showing the characteristic propodeal enclosure. The arrows point the apical prominences of the propodeum.

Color: Markedly different from combinata in the ground coloration as follows: head and thorax purple with green tint; metasoma beautiful purple with slight green tint; legs purple with apex of each segment of tarsi reddish brown; wings less yellowish than in combinata with veins, stigma and tegulae more brownish. In regard to yellow markings: mandibles entirely black; spear head-like mark on supraclypeal area not separated by median sulcus below ; collar of pronotum entirely purple ; yellow markings on other parts of thorax similar to combinata but smaller, especially on tubercle, prepisternum and scutellum; basal yellow markings on tibiae broader than in combinata. In the holotype, the markings are not yellow but reddened, and it is supposed that the color is thus changed by the killing agent.

Pubescence: Similar to combinata except for covering of short dense hairs on lateral face of propodeum more greyish and less brownish and hairs on legs less reddish and more greyish.

Type material : Holotype female (BISHOP 11279), Bougainville, Kukugai Vill., 150 m, Solomon Is., xii. 1960 (W. W. Brandt).

Type depository : B. P. Bishop Museum, Honolulu.

Distribution : Solomon Is.

\section{Species group of montana}

Palaeorhiza (Palaeorhiza) mon tuna sp. $\mathrm{n}$. 
This species is distinctive in having the head and thorax steel blue and the metasoma purple. This mode of the ground coloration is similar to the following species, purpureoventris. However, the light markings of this species are primarily limited to the head alone, three stripes in front and two of them behind, although the latter is weak in the male. The longitudinal ridges on the mesoscutum are distinct. In the male, the parapsidal lines are also well marked. In the female, the legs, especially the hind tibiae, are slender and the apex of the last exposed tergum is distinctly produced apically, and unlike other species of the subgenus, the latter is not provided with the incomplete pygidial plate.

Female: Length about or slightly less than $9 \mathrm{~mm}$, more or less slender; wing length slightly less than $8 \mathrm{~mm}$.

Relative head measurements : width, 7.4 ; length 6.7 ; eye length, 5.3 ; upper interocular distance, 4.0 ; width of face, 4.8; lower interocular distance, 3.6 ; clypeal length, $1.9: 0.9$. Inner eye margins moderately converging below except for upper one-fourth which converges toward ocelli ; mandibles weakly tridentate ; median process of labrum weakly excavated beneath; malar space longer than in the four preceding species, about one-half as long as basal width of mandible in middle, slightly broadened posteriorly ; face convex ; upper portion of supraclypeal area more convex as seen in profile; ocelli more or less small; postocellar distance slightly longer than long axis of lateral ocellus, about two-thirds as long as ocellocular distance, the latter a little shorter than ocelloccipital distance; space between ocelli and preoccipital carina distinctly slanting, transversely slightly concaved on posterior portion ; genal area slightly narrower than eye as seen in profile, receding. Collar of pronotum not strongly convex, slightly arched with median portion nearly straight as seen in front, slightly narrowed and rounded dorsally in middle; mesoscutum with a pair of longitudinal ridges distinct and long ; scutellum and metanotum largely nearly flat ; propodeal enclosure almost all dorsal, subhorizontal, a little shorter than scutellum, longitudinally broadly concaved apically ; apical prominences of propodeum distinct; ridge in front of mid coxa moderate. Stigma rather broad; second submarginal cell large, about five-sixths as long as first, first abscissa more than half of first transverse cubital, nearly twice as long as third abscissa. Legs slender; hind tibiae slender, especially so basally, basitibial area not well indicated ; inner hind tibial spur distinctly pectinate. Metasoma long, nearly parallel-sided, with second and third terga broadly exposed; second tergum with base strongly constricted, median portion strongly convex dorsally as seen in profile; second sternum short, apical margin strongly emarginate, therefore basal portion of third sternum largely exposed; apical margins of two following sterna also distinctly emarginate.

Clypeus densely lineolate, weakly and rather sparsely punctate; lower supraclypeal area longitudinally more lineolate, largely impunctate in middle ; frons moderately strongly punctate on microscopically lineolate ground, punctures rather sparse, irregular in distribution ; lower paraocular area weakly lineolate-punctate ; interocellar space broadly impunctate posteriorly ; space between lateral ocellus and upper limit of facial fovea impunctate; genal area sparsely punctate on weakly lineolate ground except for space near orbit smooth and impunctate. Mesoscutum rather strongly punctate on nearly smooth (microscopically tessellate under high 
magnification) and weakly shining ground, punctures subcontiguous to about two puncture widths apart; punctures on anterior portion of mesoscutum hardly weakened, or only slightly smaller than those on median and posterior portions; scutellum more sparsely punctate than in mesoscutum ; metanotum weakly and sparsely punctate, nearly smooth basally ; propodeal enclosure weakly lineolate, weakly shining; lateral face of propodeum more or less coarsely sculptured in consequence of close, small and roughened punctures ; pre- and mesepisternum rather sparsely punctate on microscopically lineolate, shining ground, punctures irregular in size and slightly so in distribution, subcontiguous to two puncture widths apart; suprascrobal area sparsely, weakly punctate ; metepisternum with punctures indistinct. Metasoma shining; first tergum weakly, second slightly more strongly, third more strongly, rather sparsely punctate ; second tergum largely smooth and highly shining in middle; impunctate apical margin of first tergum narrow, poorly indicated, that of second rather broad, well indicated, about as broad and distinct as that of third; sterna strongly punctate.

Color: Head and thorax dark steel blue with purple and partly brassy tints; following markings pale yellow with partly slight blue tint: broad median stripe of face extending from apex of clypeus to upper portion of supraclypeal area (tip of stripe broadly separated from mid ocellus), lateral stripes of face extending from anterior basal articulations of mandibles to near tops of eyes, and long stripes along hind margins of eyes (these pale markings in the holotype female irregularly reddened supposedly because of killing agent). Wings pale yellowish brown, distal margins slightly darkened; veins reddish brown, stigma darker; tegulae reddish brown. Legs reddish brown with slight purple tint; fore tibiae broadly yellowish brown anteriorly. Metasoma shining purple with slight green tint; green tint more or less distinct on third and fourth terga.

Pubescence: Hairs whitish except for those on apical segments of metasoma brown; white covering of short hairs on lateral face of propodeum not conspicuous.

Male: Length about or slightly over $9 \mathrm{~mm}$; wing length slightly over $8.5 \mathrm{~mm}$.

Relative head measurements : width, 7.8; length, 7.3 ; eye length, 6.0; upper interocular distance, 4.3 ; width of face, 5.0 ; lower interocular distance, 3.6; clypeal length, 2.1 :1.1. Differs from the description of female as follows : mandibles bidentate ; malar space more than one half as long as basal width of mandible (thus, longer than in female); face broadly nearly flat ; median sulcus of supraclypeal area distinct ; frontal line elevated; space behind ocelli subhorizontal. Apical prominences of propodeum large and conspicuous; propodeal enclosure more concaved than in female, lateral margins poorly indicated ; posterior face of propodeum large, steep; transverse carinae in front of mid coxae strong. Second submarginal cell of fore wings slightly smaller than in female, about three-fourths as long as first. Legs slightly stouter than in female with claw-segments and claws large; hind tibial spurs normal. Metasoma with first tergum large, distinctly convex at median basal angle, apical portion transversely distinctly concaved; second tergum with a pair of low, large, lateral convexities; similar convexities on first and third terga not distinct; apical margin of second sternum triangularly produced apically in middle ; third sternum with a pair of strong ridges converging apically, apical margin nearly straight; fourth sternum with a pair of large, low, median convexi- 
ties basally, apical margin slightly emarginate in middle; apical margins of fourth and fifth terga each with a row of fringe of long hairs.

Clypeus distinctly longitudinally striate-punctate ; frons more strongly punctate than in female, although punctures irregular in distribution as in female; mesoscutum strongly and densely punctate on minutely tessellate ground ; lateral face of propodeum less coarsely sculptured than in female, with very close and fine punctures; punctures on pre- and mesepisternum slightly closer than in female. Impunctate apical margin of first tergum broad in middle.

Color : Similar to female except as follows : markings on head orange ; stripes on face broader, and those on genal area much narrower and shorter; stripe on supraclypeal area separated or nearly so in middle, and upper mark spear headlike; fore tibiae broadly yellowish brown anteriorly.

Pubescence: More hairy than in female; hairs white except for those on apical segments of metasoma blackish; concavity of underside of thorax with hairs snow white, downy, not specially dense ; white hairs on latero-apical portions of first tergum rather dense and fringe-like; hairs on outer faces of hind tibiae long and rather coarse, nearly perpendicular to surface from which they occur when seen from behind.

Type material : Holotype female (BISHOP 11280), Wisselmeren : Enarotadi, 1,800 m, W. New Guinea, 1. viii. 1955 (J. L. Gressitt) ; 2 paratype males, Wisselmeren : Waghete, Tigi L., 1,700 m, 18. viii. 1955 (J. L. Gressitt), in the collection of Bishop Museum; 1 paratype male, same locality as the preceding, 13. i. 1955 (L. D. Brongersmacs), in the collection of LEIDEN.

Type depository : B. P. Bishop Museum, Honolulu.

Distribution: W. New Guinea.

(6) Palaeorhiza (Palaeorhiza) purpureoventris Hirashima

Palaeorhiza purpureoventris Hirashima, 1975, J. Fac. Agr., Kyushu Univ., 20 : 32, male. Type locality: Paniai $1750 \mathrm{~m}$, Wisselmeren, W. New Guinea.

This species is known from the holotype male only. It is a large, beautiful species tinged in shining steel blue (the head and thorax) and purple (the metasoma), having the pale markings on the head and thorax.

The longitudinal ridges on the mesoscutum are not very distinctive, and they are pale yellow, with bluish tint, in color.

The apical prominences of the propodeum in the male of this species are very distinctive, and the propodeal enclosure is deeply concaved between them. These features are more distinct than in the preceding species.

Type depository : Rijksmuseum van Natuurlieke Historie, Leiden.

Distribution: West New Guinea.

\section{Species group of perviridis}

\section{(7) Palaeorhiza (Palaeorhiza) perviridis (Cockerell)}

Prosopis perviridis Cockerell, 1905, Ann. Mag. Nat. Hist., (7) 16: 401, female. Meroglossa perviridis cassiaefloris Cockerell, 1910, Ann. Mag. Nat. Hist., (8): 6: 22, female. 
So far as I am aware, this species has been confused with Palaeorhizareginarum (Cockerell). For example, even Cockerell (1929) missidentified caeruZescens, which, in my opinion, is a very close relative of perviridis or might be a synonym of the latter, as a sononym of reginarum. A female specimen of perviridis, now in the collection of the University of Kansas, was identified as reginarum by $\mathrm{R}$. E. Turner. A male specimen of perviridis in the same institution is also identified as reginarum, although the determiner is unknown. As a matter of fact, the two species are very close to each other, but they are independent species and are well distinguishable by a number of characters as shown in this paper.

On the other hand, perviridis itself is polymorphic and complex, and a comprehensive study of it is necessary in future.

Female: Length, with apical segments of metasoma retractile, about or less

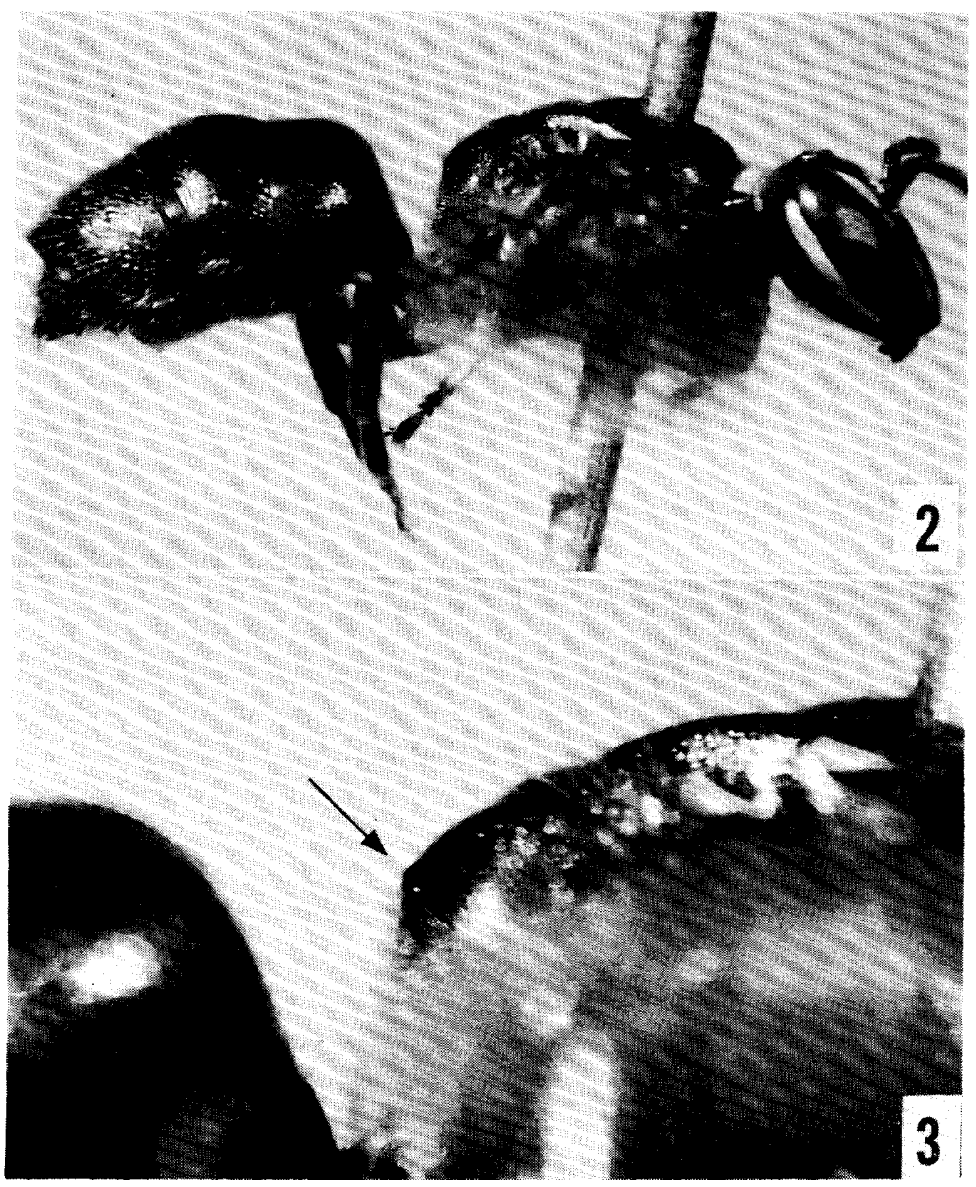

Figs. 2 and 3: Palaeorhiza perviridis, female. 2: The habitus, lateral view. 3 : Enlargement of the posterior part of thorax, showing (by an arrow) the apical prominence of the propodeum. 
than $9 \mathrm{~mm}$; wing length, up to $7.5 \mathrm{~mm}$.

Relative head measurements : width, 8.1; length, 7.3 ; eye length, 6.0; upper interocular distance, 4.3 ; width of face, 5.3 ; lower interocular distance, 3.8; clypeal length, 2.2 : 0.8. Inner eye margins distinctly converging below except for upper one-fourth which distinctly converges toward ocelli ; mandibles slightly tapering toward bidentate apices, with upper teeth broader than lower ones; labrum with weak median process slightly triangularly excavated beneath; rnalar space about one-fourth as long as basal width of mandible, slightly widened posteriorly (slightly shorter than in reginarum); clypeus with three longitudinally raised areas, median one narrower ; clypeo-ocular distance longer than in the abdominalis subgroup; supraclypeal area well convex, slightly dilated in middle, with long, strong, median sulcus not distinctly differentiated from weaker frontal line; ocelli rather small; postocellar distance a little less than twice as long as diameter of lateral ocellus, a little shorter than ocellocular distance ; the latter slightly shorter than ocelloccipita1 distance ; space behind ocelli moderately slanting toward preoccipital carina ; genal area rather receding, narrower than eye when seen from side. First flagellar segment about as long as broad or a little broader than long; second a little shorter than first; third about as long as broad, slightly longer than first. Collar of pronotum rather low, dorsal margin only slightly arcuate as seen in front, rather thick laterally, narrowed and subcarinate medially ; mesoscutum well convex ; scutellum, metanotum and propodeal enclosure successively gently slanting when seen from side ; propodeal enclosure broad, defined by strong, usually punctate sulcus laterally, about one and one-half times as long as metanotum, broadly convex except for apical portion which is noticeably concaved; about apical one-third of enclosure on vertical face of propodeum, almost triangular; apical prominences of propodeum small but distinct, distance between them longer than in the species of the two preceding species subgroups; carina in front of mid coxa distinct. Stigma of wings slender, subparallel-sided; second submarginal cell about two-thirds as long as first; first abscissa of second submarginal cell shorter than one-half of first transverse cubital, longer than third abscissa which is about equal to or
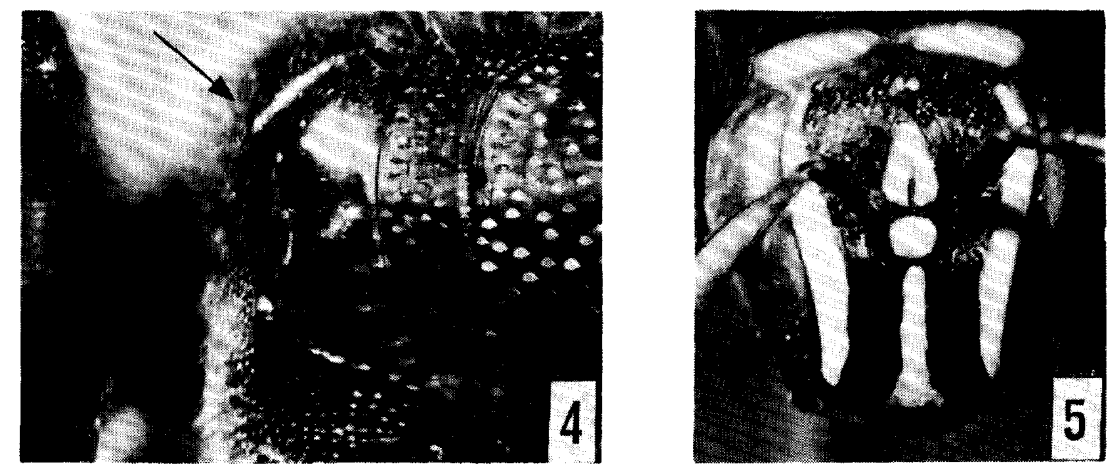

Figs. 4 and 5. Palaeorhiza perviridis, female. 4: Dorsal view of the posterior part of the thorax, showing the characteristic propodeal enclosure. The arrow points one of the apical prominences of the propodeum. 5: Front. view of the head. 
slightly longer than two vein widths. Legs rather slender; basitibial area well indicated by raised, elongate (but not specially long), impunctate space ; inner hind tibia1 spurs pectinate, teeth much smaller than in the species of the abdominalis subgroup. Metasoma with apical segments usually retractile (apical segments usually not retractile in reginarum); first tergum with midbasal portion well convex, latero-basal portions also well convex laterally when seen from above; second tergum convex medially, strongly so as seen in profile; apical margin of second tergum gently produced apically in middle (best seen from above); third tergum largely exposed ; sixth tergum with incomplete pygidial plate well indicated ; second sternum rather short, apical margin broadly emarginate, with median portion often slightly produced apically ; basal portion of third sternum broadly transversely depressed.

Clypeus very weakly punctate, punctures longitudinal, weaker than those on lower paraocular areas ; longitudinal lineolation of lateral portion of clypeus about as strong as that of lower paraocular areas; lower portion of supraclypeal area more distinctly lineolate with very weak, longitudinal punctures; frons lateral to upper supraclypeal area broadly impunctate, very finely lineolate, shining; rest of frons and vertex moderately strongly, densely punctate; genal area weakly, sparsely punctate on smooth, highly shining ground near eye margin, somewhat coarsely, more or less sparsely punctate on lineolate ground on posterior portion. Collar of pronotum very finely, densely punctate dorsally ; mesoscutum rather strongly punctate on microscopically tessellate and distinctly shining ground ; punctures on mesoscutum irregular in distribution, contiguous to two puncture widths apart on median portion, those on anterior margin not very weakened; scutellum more sparsely punctate than in mesoscutum, punctures irregular in size and distribution; metanotum weakly, sparsely punctate, punctures on median portion weaker than those on lateral portion ; propodeal enclosure finely lineolate, shining ; dorsolateral and posterior faces of propodeum densely, moderately strongly punctate, punctures sparser near enclosure ; apical prominences of propodeum impunctate ; lateral face of propodeum very closely punctate on microscopically roughened, more or less dull ground ; pre- and mesepisternum distinctly punctate on microscopically tessellate and shining ground, punctures rather sparse (subcontiguous to distinctly separated), slightly weaker than those on mesoscutum; suprascrobal area (upper portion of mesepisternum above the spiracle) distinctly punctate, punctures about as strong as those on lower portion of it; metepisternum very closely and weakly punctate on microscopically roughened ground (punctures smaller and closer than in reginarum). Metasoma moderately to strongly punctate on minutely tessellate, more or less dull to shining ground; punctures on median portions of basal two terga weaker than those on lateral portions of the same tergum; punctures on second tergum stronger than those on first, those on third roughened, large and shallow; impunctate apical margin of first tergum narrow, obsolescent at lateral portions, that of second tergum broad and well indicated, slightly narrowed at extreme sides because of very fine and close punctures, that of third like that of second but not narrowed at sides; sterna very strongly punctate.

Color: Beautiful green with slight brassy tint, or sometimes with blue and purple tints especially on metasoma; yellow markings on head, thorax and legs as 
follows : three stripes on face, the median one enlarged at apical portion of clypeus, interrupted in middle of supraclypeal area and narrowly so between clypeus and supraclypeal area, the upper mark on supraclypeal area spear head-like and pointed above, separated by median sulcus below, long stripes on genal areas along eye margins, band on collar of pronotum interrupted medially, narrow line on trans scutal suture of mesoscutum, spot on upper portion of prepisternum and basal marks on fore tibiae ; sometimes tubercles with apical spots and mid tibiae with basal spots. Legs piceous with strong green and slight purple tints; anterior faces of fore tibiae yellowish brown. Wings hyaline, scanty of hairs ; cell first Cu of fore wings free of hairs (wings dusky with denser hairs in reginarum) ; veins and stigma brownish.

Pubescence: Hairs white except for those on two apical segments of metasoma blackish (at least three apical segments of metasoma with black hairs in reginarum); hairs on lateral face of propodeum not conspicuous.

Male: Slenderer than female.

Relative head measurements : width, 7.5 ; length, 7.2 ; eye length, 5.7 ; upper interocular distance, about 4.0; width of face, 4.7; lower interocular distance, 4.2; clypeal length, 2.2 : 0.8. Differs from the description of female as follows : head receding below in front view; inner eye margins strongly converging below except for upper one-fifth which converges toward ocelli; mandibles slightly tapering toward bidentate apices ; malar space about one-half as long as basal width of mandible ; clypeus with three longitudinally raised ridges weaker than in female; clypeo-ocular distance slightly longer than in female; postocellar distance as long as ocellocular distance. Scape about three times as long as broad; third flagellar segment slightly longer than broad. Collar of pronotum carinate in middle dorsally; propodeal enclosure narrower and more concaved apically than in female; distance between apical prominences of propodeum shorter than in female; carinae in front of mid coxae strong; concavity of underside of thorax broad and deep, although not sharply defined (very distinctly indicated by presence of dense white hairs in reginarum). Second submarginal cell of fore wings shorter than twothirds of first; first abscissa of the former as long as (on the right wing) or shorter than third abscissa (only one specimen examined). Legs stouter than in female; claws strong; claw segments, especially those on hind legs, enlarged ; hind tibia1 spurs normal ; basitibial areas of hind legs weakly indicated. Metasoma elongate, gently converging apically when seen from above; fiirst tergum broad, rather long, midbasal portion well convex, subapical portion transversely depressed or constricted; second tergum more convex in middle than in female, distinctly constricted basally; apical margin of second tergum almost transversely straight or median portion less produced apically than in female; lateral portions of second and third terga convex subapically (basal to apical impunctate margins) ; apical margin of second sternum triangularly produced apically in middle ; third sternum with a pair of longitudinal ridges reaching apical impunctate margin which is more or less broad, well indicated; fourth sternum with a pair of low prominences midbasally; apical portion of the same sternum with tuft of hairs which are not arranged in a transverse row (following sterna not examined).

Head nearly smooth, more shining than in female except as follows: clypeus, 
lower paraocular areas and posterior portions of genal areas microscopically lineolate; lower portion of supraclypeal area very weakly striate in middle. Mesoscutum and metanotum slightly more densely punctate than in female; punctures on mesoscuturn becoming weaker anteriorly. Metasoma, especially first tergum, more strongly and densely punctate than in female; punctures on median portion of first tergum hardly weaker than those on corresponding portion of second ; laterobasal portions of third and fourth sterna longitudinally densely striate-punctate ; these portions remarkable when compared with neighbouring spaces which are strongly punctate on smooth shining ground.

Color: Slightly more bluish than in female, blue-green, with purple tint especially on genal area, pronotum, propodeum and two basal terga; yellow markings similar to female except as follows: mark on clypeus large, triangular, extending as a stripe above and not reaching summit of clypeus ; lower mark on supraclypeal area narrower and upper mark, which is spear head-like, smaller.

Pubescence: White as in female except for black hairs on apical metasomal segments; apical hair tuft on fourth sternum brownish.

Specimens examined : 1 male (no data), 1 female (Kuranda, F. P. Dodd, determined as Palaeorhiza pervirids by Cockerell), and 1 female (Mackay, determined as Palaeorhiza reginarum by R. E. Turner in 1929) in the University of Kansas; 3 females (Cairns, F. P. Dodd, det. by Cockerell) and 1 female (Brisbane, H. Hacker, 15. I. 1912) in Queensland Museum ; 1 female (Kuranda, F. P. Dodd) in Smithsonian Institution; 1 female (Mackay, Voyage Eugenies Resa) in Museum Paris; 1 female (Cocktown) in University Museum Copenhagen ; 1 female (Bundaberg, F. Muir, 8-1919) in Bishop Museum.

Type depository: British Museum (Natural History), London.

Distribution : Australia.

Remarks : I have seen the type of this species at British Museum in 1967. I am not very sure that the subspecies cassiaefioris described by Cockerell, the type of which is also in British Museum, is conspecific with perviridis. I was impressed that the face of cassiaefloris is longer than in perviridis. Among the specimens mentioned above, a female from Bundaberg in Bishop Museum seems to be cassiaefloris, or might be determined as caerulescens (see below), and a female from Brisbane in Queensland Museum might be a good subspecies. Brief description of the latter is as follows:

Female: Length $9 \mathrm{~mm}$; wing length $7 \mathrm{~mm}$.

Apical segments of metasoma not retractile; integument of head more roughened except for clypeus, lateral portion of which is a little smoother than in lower paraocular area; punctures on frons and genal areas near eye margins stronger ; mesoscutum and scutellum more convex; the former nearly smooth anteriorly ; metanotum almost horizontal, more roughened, with stronger punctures laterally ; propodeum more roughened ; pre- and mesepisternum smoother except for suprascrobal area; metepisternum and lateral faces of propodeum more punctate ; metasoma more roughened.

Color: Clypeus with purple tint, especially lateral to median yellow stripe which is more broadened beneath; mesoscutum, scutellum, pre- and mesepisternum largely dark purple ; second and following terga blue green with purple tint ; legs 
more purple ; markings on head, thorax and legs nearly cream yellow; upper mark on supraclypeal area smaller, broadly separated from mid ocellus; mark on prepisternum below tegulae evanescent; anterior face of fore tibiae not at all yellowish; basal mark of mid tibiae small ; flagellum beneath darker, reddish brown.

\section{(8) Palaeorhiza (Palaeorhiza) caerulescens (Friese)}

Prosopis caerulescens Friese, 1924, Konowia, 3: 223, female.

This is not a synonym of reginarum as Cockerell (1929, Amer. Mus. Novit., 343: 16) has pointed out. I am not very sure, however, whether this is a good species or not. If not, caerulescens is a synonym of perviridis. The following is the redescription of the "so-indicated " type" of caerulescens now kept in the collection of the American Museum of Natural History, New York.

Female : Length about $10 \mathrm{~mm}$; wing length about $8 \mathrm{~mm}$.

Relative head measurements : width, 8.7; length, 7.7 ; eye length, 6.4 ; upper interocular distance, 4.6; width of face, 5.6 ; lower interocular distance, 4.2 ; clypeal length, $2.4: 0.9$. Differs from the description of perviridis as follows: apical segments of metasoma as usual or only slightly retractile; mandibles tapering toward bidentate apices ; malar space indistinctly longer ; clypeus and supraclypeal area distinctly more convex as seen in profile ; postocellar distance five-sixths as long as ocellocular distance ; vertex with a very weak longitudinal line behind mid ocellus; genal area slightly narrower than eye, slightly convex above. Collar of pronotum more narrowed and almost carinate in middle; scutellum rather flat apically. First abscissa of second submarginal cell one-half as long as first transverse cubital on the right wing, longer on the left one. Apical margin of second tergum scarcely produced apically in middle.

Lateral portion of clypeus slightly more roughened, duller ; frons more densely punctate on smoother ground; mesoscutum slightly more densely and slightly more strongly punctate, punctures more regular in distribution; third tergum without very fine punctures along lateral margins (in perviridis, at least a row' of very fine punctures along lateral margins, which are easily distinguishable in size from coarse punctures on the same portions).

Color: Head and thorax greenish blue with purple tint; propodeal enclosure entirely purple as seen in certain angles ; two basal terga blue with strong purple tint ; third and following terga blue green with purple tint which is strong on apical portion of third tergum ; underside of metasoma blue with strong purple tint. Markings on head, thorax and legs paler, cream yellow; upper mark on supraclypeal area smaller, widely separated from mid ocellus; anterior faces of fore tibiae scarcely yellow ; mid tibiae without basal yellow marking (tubercles also without yellow marking).

Distribution : Australia.

\section{(9) Palaeorhiza (Palaeorhiza) reginarum (Cockerell)}

Prosopis reginarum Cockerell, 1905, Ann. Mag. Nat. Hist., (7): 16 : 402, female.

This is a very close relative of perviridis, but is distinguished from it by the 
following characters.

Female : Larger than perviridis. Integuments of head and thorax slightly more lineolate or tessellate; supraclypeal area often more convex as seen in profile ; malar space slightly longer ; collar of pronotum slightly more convex dorsally, more narrowed and almost carinate medially; apical margin of second tergum less produced apically in middle; apical segments of metasoma usually not retractile. Punctures on lateral portions of clypeus a little stronger (although weak); punctures on mesoscutum slightly closer (although variable), and often stronger. Principally blue species, with slight purple and brassy tint; apical metasomal segments often blackened; light markings slightly less developed (stripes on head narrower and marks on pronotum smaller), creamy white ; upper mark on supraclypeal area separated in middle by median sulcus; transscutal suture of mesoscutum (stated as " axilla" in the original description) without yellow marking, although inner apical corner narrowly yellowish; rarely axillae and sides of scutellum with small yellow marks close together; mid tibia usually without basal mark. Wings darkened, with dense hairs ; cell first $\mathrm{Cu}$ of fore wings with hairs. Third tergum with hairs largely black; three apical metasomal segments with hairs black.

M ale: Easily separable from perviridis in having a very dense covering of white hairs on concavity on underside of thorax. Other differences similar to female except as follows : fourth sternum with a pair of low prominences punctate; in gigantic form, longitudinal ridges on third sternum well developed, almost reaching apical margin of sternum ; mandibles with evanescent to distinct pale yellow spots ; tubercle with yellow spot apically; axillae and scutellum with or without small (or evanescent) yellow marks, close each other when present.

Specimens examined : 1 female (Logan, Queensland, determined as Palaeorhiza reginarum by Cockerell) in the University of Kansas; 2 females (Brisbane, $\mathrm{H}$. Hacker, det. by Cockerell), 1 male (Hy 899), 1 gigantic male (Stradbroke Island, off Brisbane, H. Hacker, det. as the female of reginarum by Cockerell) in 'Queensland Museum; 1 male (Mackay) in Smithsonian Institution; 1 male (Makcay, det. by R. E. Turner) and 1 female in CSIRO; 1 male in University Museum Copenhagen ; 1 female (Mackay, det. as Meroglossa reginarum by Cockerell) in California Academy of Sciences ; 2 females and 3 males (Mackay, Voyage Eugenies Resa) in Museum Paris.

Type depository: British Museum (Natural History), London.

Distribution : Australia.

Remarks: I have seen the type of this species at British Museum. It is the male, not the female as shown in the original description. Cockerell recorded the male in Ann. Mag. Nat. Hist., (8) $6: 22$.

\section{Species group of malachisis}

\section{(10) Palaeorhiza (Palaeorhiza) malachisis (Smith>}

Prosopis malachisis Smith, 1859, J. Proc. Linn. Soc. London, Zool., 3: 132, female.

This is a dark green species. The absence of the yellow marking and the presence of the blackish hairs on the body are characteristic features of the female 
of this species. The coloration of the integument, although the frons is not brassy, recalls that of Palaeorhiza turneriana from Australia which belongs, however, to the different subgenus.

Female: Length about $10 \mathrm{~mm}$,

Relative head measurements : width, 8.6; length, 7.7 ; eye length, 6.5; upper interocular distance, 4.3 ; width of face, 5.3; lower interocular distance, 3.6; clypeal length, $2.6: 0.8$. Eyes rather large as seen in front; inner eye margins strongly converging below except for upper one-fourth which strongly converges toward ocelli; mandibles weakly tridentate, or in other words, bidentate with a distint tooth-like angulation at inner apical corner; malar space about one-fourth as long as basal width of mandible, more or less distinctly narrowed anteriorly (narrower than in perviridis) ; face well convex and its outline slightly arcuate as seen in profile; clypeus with median longitudinally raised area obscure beneath ; clypeoocular distance short (shorter than in perviridis) ; supraclypeal area dilated medially, upper portion longitudinally well convex and well differentiated from frons laterally; median sulcus of supraclypeal area broad, long and deep, frontal line much weaker and shorter than the latter; postocellar distance one and one-half times as long as diameter of lateral ocellus, a little shorter than ocellocular distance, about twothirds as long as ocelloccipital distance ; space behind ocelli rather strongly slanting toward preoccipital carina. Collar of pronotum low, narrow, subcarinate in middle, rounded laterally; aspects of propodeal enclosure and apical prominences similar to those of perviridis and reginarum; carinae in front of mid coxae strong. Wings with stigma slender, subparallel-sided; second submarginal cell larger than in perviridis ; first abscissa of second submarginal cell more or less long, about or more than twice as long as third abscissa. Legs similar to perviridis; basitibial area also well indicated. Metasoma well convex as seen in profile ; unlike perviridis and reginarum, median portion of second tergum not distinctly convex, and median portion of apical margin of the same tergum only indistinctly produced apically; sixth tergum with incomplete pygidial plate well indicated.

Clypeus longitudinally lineolate, more or less dull, longitudinal wrinkles on median portion distinct; punctures on clypeus distinct in middle, feeble at sides; genal area distinctly and more or less densely punctate, punctures still distinct near eye margin; frons lateral to supraclypeal area broadly impunctate; rest of frons and vertex strongly and densely punctate. Mesoscutum densely and distinctly punctate (more densely punctate but punctures- smaller than in reginarum), punctures slightly weakened on anterior portion ; scutellum strongly punctate, punctures sparse and irregular in distribution and in size, but most of them stronger than those on mesoscutum ; metanotum very weakly punctate ; propodeal enclosure slightly more lineolate, so that less shining, than in perviridis; rest of propodeum densely punctate : pre- and mesepisternum very densely and rather strongly punctate including suprascrobal area, punctures as strong and dense as those on mesoscutum lateral to parapsidal line ; metepisternum densely and weakly punctate ; lateral face of propodeum slightly more roughened than in perviridis because of closer punctures. Metasoma slightly more weakly punctate than in perviridis; impunctate apical margin of first tergum not well indicated, obsolescent laterally, that of second broad in middle (slightly broader than in perviridis), narrowed at 
extreme side because of presence of fine punctures, that of third also broad in middle.

Color : Dark green with strong purple and slight blue tints; purple tint strong on head (genal area almost all purple); legs piceous with strong purple and slightly blue-green tints ; anterior face of fore tibia yellowish without lens, metasoma dark blue-green, more shining than in head and thorax. Wings darkened, veins and stigma brown, hairs blackish and dense (hairs about as dense as in reginarum but sparser than in the abdominalis group). Tegulae brown with blue-green tint.

Pubescence: Hairs on body, including legs, fuscous to black except for metanotum, propodeum and lower half of metepisternum with hairs dark grey or whitish.

Specimen examined: 1 female (Key Ins., 1900, Kühn, det. as Prosopis malachisis Sm. by Friese, in 1908) in the University of Kansas.

Type depository: British Museum (Natural History), London.

Distribution: Kai, also Amboina (see below).

A male specimen from Amboina (F. Muir) in the Smithsonian Institution, which is determined as Palaeorhizaimperialis Smith by Bridwell in 1919, seems to be the male of malachisis. Brief description of it is given below.

Male: Length slightly less than $11 \mathrm{~mm}$; wing length, $8 \mathrm{~mm}$.

Relative head measurements: width, 8.0; length, 7.8; eye length, 6.4; upper interocular distance, 4.1; width of face, 4.7; lower interocular distance, 2.9; clypeal length, 3.5 ; scape length, 1.9 ; scape width, 0.7 ; postocellar distance, 0.9 ; ocellocular distance, 0.9 ; ocelloccipital distance, 1.3. Malar space distinct, one-half as long as basal width of mandible; median part of clypeus longitudinally wrinkled, especially above, with weak punctures; lower half of supraclypeal area like clypeus or a little more coarsely punctate ; frons and vertex densely, strongly punctate like reginarum ; genal area more strongly punctate than in reginarum; collar of pronotum linear in middle like female; mesoscutum with denser but weaker punctures than in reginarum, although they are distinct ; mesepisternum densely and strongly punctate like anterior portion of mesoscutum, more closely punctate than in reginarum ; metasoma strongly punctate like reginarum ; second less convex than in reginarum; covering of white hairs of concavity on underside of thorax sparser than in reginarum, far more conspicuous than in perviridis; metasoma with more black hairs, including sterna, than in reginarum; second submarginal cell receiving second recurrent vein more close to end of cell than in perviridis.

After the above note was made in 1967 at the Smithsonian Institution, I was able to see one male specimen also from Amboina (July 23, 1962, A. M. R. Wegner) in Museum Leiden. It is also identified here as the male of malachisis. Brief description of it is as follows:

Agrees in general habitus with female except for sexual differences; more purple than in female, with pale yellow markings on head and legs as follows : apical triangular mark on clypeus, lateral stripes of face not extending above beyond middle of supraclypeal area, a pair of small spots on median portion of supraclypeal area, and anterior faces of fore tibiae ; flagellum with first segment about as long as broad, second broader than long and longer than first, third slightly shorter than first and second together; propodeal enclosure smaller than in female as usual, apical portion distinctly concaved; distance between apical 
prominences of propodeum shorter than in female; third sternum with a pair of ridges weak and short, and fourth sternum with a pair of low prominences also not conspicuous; unlike perviridis and reginarum, third and fourth sterna without striated portions laterally ; mesoscutum more densely punctate than in female; pre- and mesepisternum including suprascrobal area very densely and distinctly punctate as in female, punctures as strong as those on anterior portion of mesoscutum; metepisternum distinctly punctate; ventral portion of first tergum broadly well punctate as in female ; hairs on head and thorax paler than in female; apical portion of fourth sternum neither with fringe nor tuft of hairs; slender and rather small, length about $9 \mathrm{~mm}$.

\section{Species group of violacella}

\section{Lectotype designation of Prosopis uiolacea Friese}

Prosopis violacea Friese, 1924, Konowia, 3: 230, male.

Friese described Prosopis uiolacea from " Asia Archipel-Timor und Tenimber Larat" based on two male specimens. This species is known as Palaeorhiza violacella Michener at present. I was able to examine, by the courtesy of Dr. Rozen, one of the cotypes of Friese's species which is now kept in the American Museum of Natural History. I would like to designate it as the lectotype of Prosopis uiolacea. The label reads : Asia Arch., Timor, 1901, H. Kuhn. It carries an orange "Typus" label, and named "Prosopis violascens" which is different from the published name.

\section{(11) Palaeorhiza (Palaeorhiza) violacella Michener}

Palaeorhiza violacella Michener, 1965, Bull. Amer. Mus. Nat. Hist., 130: 146. (New name for Prosopis violacea Friese, 1924, not Smith, 1853)

This species is known from the male only. Although Michener placed violacella into the subgenus Palaeorhiza, his interpretation is different from my own.

Description of the lectotype male: Length about $7.5 \mathrm{~mm}$, wing length, about $6 \mathrm{~mm}$.

Relative head measurements: width, 6.8 ; length, 6.4 ; eye length, 5.4 ; upper interocular distance, 3.6; width of face, 4.3 ; lower interocular distance, 2.4 ; clypeal length, $0.7: 2.0$. Eyes rather large as seen in front; inner eye margins strongly converging below except for upper one-fourth which converges toward ocelli; mandible tapering toward bidentate apex ; labrum convex in middle ; malar space slightly more than one-third as long as basal width of mandible; paraocular ridge, except for upper portion, rather distinct; clypeus only slightly, supraclypeal area slightly more convex when seen from side; clypeus with median carina obscure beneath and upper portion weakly extending into supraclypeal area; lateral portion of clypeus longitudinally weakly elevated except for upper one-third almost flat; clypeo-ocular distance narrower than diameter of pedicel; subantennal suture about two-thirds as long as width of clypeus at summit, a little longer than diameter of antenna1 socket; supraclypeal area slightly dilated above, upper margin not sepa- 
rated from median ridge of frons as usual for the subgenus, median sulcus broad and shallow, frontal line weakened above; ocelli rather small ; postocellar distance a little less than twice as long as diameter of lateral ocellus, subequal (on left side) or a little shorter (on right side) than ocellocular distance, about two-thirds as long as ocelloccipital distance ; facial fovea punctiform, not distinct ; space behind ocelli strongly slanting toward preoccipital carina; genal area strongly receding, about one-half as broad as eye seen from side. Flagellum rather elongate ; first segment broader than long, subequal to or very slightly longer than second; third segment slightly shorter than two basal segments together. Collar of pronotum with anterior margin emarginate when seen from above, very thin and sharply carinate dorsally in middle, dorsal margin of that portion almost straight as seen in front, lateral portion slanting laterally, more or less thick; scutellum more or less distinctly convex ; metanotum subhorizontal as seen in profile, transversely convex when seen from behind; apical prominences of propodeum very small but well noticeable; enclosure of propodeum with subhorizontal dorsal face longer than metanotum, apical portion slightly concaved between prominences; less than apical one-third of enclosure on vertical face of propodeum; carina in front of mid coxa sharp; concavity on underside of thorax distinct but not sharply defined. Stigma rather long and more or less broad, about two-thirds as long as costal margin of marginal cell; vein $r$ subequal to upper margin $(R s)$ of second submarginal cell (vein $r$ usually shorter than the latter for the genus) ; first recurrent vein ending outside second submarginal cell; second recurrent vein ending near end of second submarginal cell which is about one-half as long as first submarginal cell. Legs slender ; inner hind tibial spur very finely serrate (not ciliate) ; claws moderate, weakly bifid, prongs converging. Metasoma rather elongate, subcylindrical; first tergum rather long, well convex midbasally, apical portion slightly constricted in middle; second tergum rather distinctly convex in middle as seen in profile; apical margin of second tergum obscurely produced apically in middle; apical margin of second sternum roundly produced apically in middle; second to fourth sterna with a pair of low prominences at sides; fourth sternum with a tuft of hairs on apical portion not distinct.

Clypeus weakly punctate on microscopically, somewhat loosely lineolate and shining ground, upper portion longitudinally, more distinctly lineolate like supraclypeal area; the latter distinctly punctate above laterally; frons distinctly punctate ; impunctate space lateral to supraclypeal area more or less narrow ; upper paraocular area strongly punctate even near orbit at emargination, punctures stronger than those on frons ; lower paraocular area finely lineolate with indication of weak punctures ; impunctate, shining space lateral to each lateral ocellus; space behind ocelli strongly punctate near ocelli; genal area strongly punctate, punctures becoming coarser and longitudinal below. Mesoscutum strongly, more or less irregularly punctate on nearly smooth or microscopically lineolate and shining ground, punctures contiguous to subcontiguous, partly one or two puncture widths apart, still distinct on anterior margin; scutellum sparsely, more or less strongly punctate on smooth and shining ground; metanotum sparsely and weakly punctate on microscopically lineolate base ; propodeal enclosure nearly glabrous with indication of microscopical lineolation, shining ; rest of propodeum very densely punctate, punctures 
on lateral face scarcely weaker than those on dorsolateral face except for those on basal portion weakened and obscure; pre- and mesepisternum rather strongly, densely punctate on shining ground, punctures on suprascrobal area also distinct; metepisternum with upper portion rather distinctly punctate on minutely roughened ground, lower portion more densely punctate on slightly smoother base. First tergum distinctly, moderately densely punctate on finely lineolate, rather shining ground; second rather sparsely punctate on smoother and shinier ground, punctures on median portion weak; third and following terga with punctures roughened ; impunctate apical margin of first tergum very narrow, that of second rather broad, finely punctate at sides, that of third impunctate even at sides; sterna strongly punctate.

Color : Bright purple, including legs, except as follows: supraclypeal area, frons, ocellar region, mesoscutum and propodeum with blue-green tint; propodeal enclosure all purple or all blue-green as seen in certain angles ; mandible and malar space reddish brown ; labrum and apical margin of clypeus blackened; face with following markings ivory white : rather large apical mark of clypeus and lateral face marks extending from near anterior basal articulations of mandibles to level of antenna1 sockets, filling lower paraocular areas and narrowed from below summit of clypeus ; anterior face of fore tibiae pale yellow ; fore distitarsi yellowish. Scape and pedicel piceous with purple tint; flagellum brown above, broadly pale yellowish brown beneath. Wings hyaline with scanty hairs like perviridis; cell first $\mathrm{Cu}$ of fore wing with sparse hairs; stigma and distal veins paler than costa and basal veins, yellowish brown.

Pubescence: Hairs not conspicuous, nearly ochreous except for those on second and following segments of metasoma brown to black.

Type depository: American Museum of Natural History, New York.

Distribution : Timor.

\section{Group of two unnamed species}

\section{(12) Palaeorhiza (Palaeorhiza) sp. from New Guinea}

A female specimen from Papua New Guinea (Aroa Estate, W. of Redscar Bay, $1 \mathrm{~m}, 1 \mathrm{X}-29-1958$, J. L. Gressitt) in Bishop Museum is parasitized by a strepsipteron (two females and one male). It seems probable to me that the effect of the stylopization is slight in this specimen, but I hesitate to name it. This is the first record of Strepsiptera from Palaeorhiza.

Dull green species, with rich pale yellow markings on head, thorax and legs as follows: basal stripes on mandibles, three long stripes on face, transverse marks on vertex between ocelli and oculi, long stripes on genal areas along eye margins, band on pronotum, four stripes on mesoscutum, axillae, longitudinal marks on lateral portions of scutellum, transverse marks on lateral portions of metanotum, a pair of stripes, which converging apically, on propodeal enclosure, tubercles, transverse marks on each upper portion of pre-, meso- and meta-episternum which are combined into a transverse band, long transverse band on median portion of mesepisternum, anterior faces of fore tibiae, basal marks on anterior faces of mid tibiae, and basal halves of hind tibiae; metasoma dark blue-green, more shining 


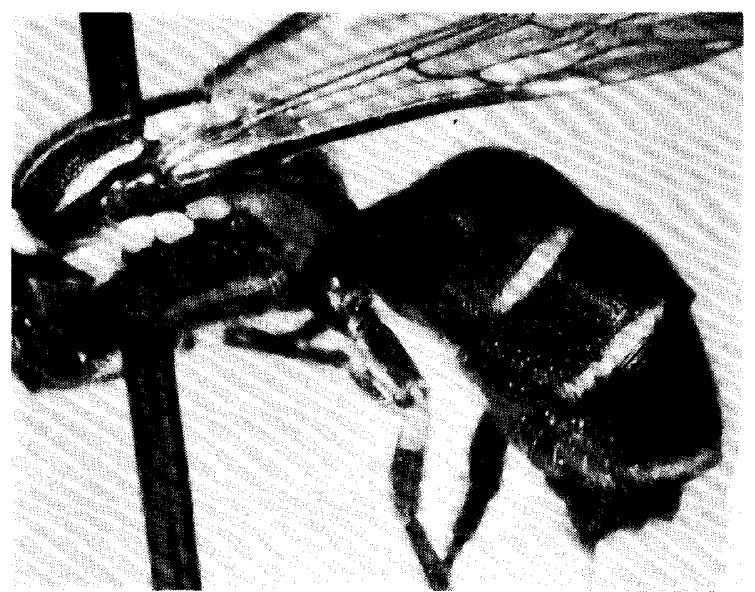

Fig. 6. Palaeorhiza (Palaeorhiza) sp. A female from Papua New Guinea, lateral view, showing the characteristic hair bands on the metasomal terga. This specimen is stylopized.

than head and thorax; basal three terga each with a broad band of short, dense and white hairs on apical margin laterally.

\section{(13) Palaeorhiza (Palaeorhiza) sp. from New Britain}

A female specimen from New Britain (Yalom 1000 m, May 20, 1962, Noona Dan Exp. 61-62) in the University Museum Copenhagen represents a new species, but the description of it will be appeared in a separate paper.

It is a blackish species with dark coppery tint and strong enamel-like lustre, and with rich yellow markings on head, thorax and legs as follows: five long stripes on head, evanescent marks on vertex between ocelli and oculi, band on pronotum, four stripes on mesoscutum, axillae, lateral marks on scutellum and metanotum, a pair of rather short stripes on propodeal enclosure, tubercle, large marks on upper portions of pre-, meso- and meta-episternum which are combined in a transverse band, stripe on mesepisternum along lower portion of prepisternal groove, anterior faces of fore tibiae, and basal marks on mid and hind tibiae. Thus, the mode of yellow markings is similar to the preceding species. Abdominal hair bands are also present in this species, although they are more broadly interrupted. Another distinctive feature of this species is that the apical prominences of the propodeum are conspicuous, and the distance between them is short.

\section{Acknowledgements}

My study on Palaeorhiza of the New Guinean region has been kindly supported by Dr. J. L. Gressitt, Wau Ecology Institute, Wau, Papua New Guinea, Dr. C. D. Michener, University of Kansas, Lawrence, Kansas, U. S. A., Dr. W. E. LaBerge, Illinois Natural History Survey, Urbana, Illinois, U. S. A., Dr. M. A. Lieftinck, Rijksmuseum van Natuurlijke Historie, Leiden, the Netherlands, and Dr. Terry Houston, University of Queensland, Brisbane, Australia. I am especially thankful 
to Dr. Gressitt, without whose help in many ways my study could not be made. I am also much indebted to the following entomologists for their help in relation to the specimens for the present study; Dr. Paul H. Arnaud, Jr., California Academy of Sciences, San Francisco; Dr. E. C. Dahms, Curator of Entomology, Queensland Museum, Brisbane; Dr. J. L. Gressitt ; Dr, A. Kelner-Pillault, Museum National d'Histoire Naturelle, Paris ; Dr. Karl V. Krombein, Smithsonian Institution, Washington, D. C. ; Dr. M. A. Lieftinck ; Dr. C. D. Michener ; Dr. B órge Petersen, Universitetetz Zoologiske Museum, Kopenhagen ; Dr. E. F. Riek, CSIRO, Canberra; Dr. J. G. Rozen, Jr., American Museum of Natural History, New York; and Dr. I. H. H. Yarrow, British Museum (Natural History), London. 